\title{
Deborah Cass, The Constitutionalization of the World Trade Organization: A Reading in Time
}

\author{
Kerry Rittich
}

\section{Introduction}

Any occasion to reflect on Deborah Cass's The Constitutionalization of the World Trade Organization (CWTO), ${ }^{1}$ serves immediately as a call to internationalists to revisit the moment and the context in which it was conceived. How to characterise that moment? At the time, it felt like a moment of not just substantial but of permanent, epochal change. The mid-1990s saw, in light of the birth of the World Trade Organization (WTO), the inauguration of a new system of multilateral trade relations, one that reposed an unusual degree of confidence in the possibility that legal rules, institutional forms and technocratic processes of adjudication might be used both to create a more fully integrated global market and to successfully regulate trade disputes within the international economic order. Other developments accompanying the birth of the WTO, however, were just as consequential to the new international order and, ultimately, to the context and manner in which the WTO operated, even if in ways not evident at its inception.

1 Deborah Z Cass, The Constitutionalization of the World Trade Organization (Oxford University Press, 2005). 
The mid-nineties was also the high-water mark of market fundamentalism. It was a moment of pervasive belief, at least among elites, in the primacy of the markets, one which saw a resurgent hope in market processes simpliciter as the source of welfare gains, as well as economic growth. ${ }^{2}$ The apparent supremacy of market ordering extended to the political realm, leading to a fusion of markets and democracy in the liberal imaginary, what Susan Marks has called the 'end of ideology' ideology that market-centred democracy represented the 'end of history'. ${ }^{3}$

As market fundamentalism became established as normative across the international order and international institutions and economic technocrats began to give pride of place to the efficient facilitation of investment and transactions across borders in the order of concerns, they also consolidated a consensus view about good governance supporting that venture, successfully disseminating templates for domestic institutional and regulatory reform in its supposed image. ${ }^{4}$ The ascendance of market fundamentalism and its associated governance priorities and projects marked an important waypoint in the decline and disintegration of the embedded liberal compromise, ${ }^{5}$ the severance of two projects that had been imagined as indissoluble parts of the postwar economic order: liberalised trade at the global level, accompanied by protection against the destabilising social and political consequences that economic integration and restructuring inevitably entail at the national level, realised through some combination of domestic monetary, fiscal, social and industrial policies. ${ }^{6}$

2 Joseph E Stiglitz, 'Is There a Post Washington Consensus Consensus?' in Narcís Serra and Joseph E Stiglitz (eds), The Washington Consensus Reconsidered: Towards a New Global Governance (Oxford University Press, 2008) 41, doi.org/10.1093/acprof:oso/9780199534081.003.0001.

3 Susan Marks, The Riddle of All Constitutions: International Law, Democracy, and the Critique of Ideology (Oxford University Press, 2000), doi.org/10.1093/acprof:oso/9780199264131.001.0001; Francis Fukuyama, 'The End of History?' (1989) 16 The National Interest 3; Francis Fukuyama, The End of History and the Last Man (Avon Books, 1992).

4 John Williamson, 'Democracy and the "Washington Consensus"' (1993) 21 World Development 1329 .

5 John G Ruggie, 'International Regimes, Transactions, and Change: Embedded Liberalism in the Postwar Economic Order' (1982) 36 International Organization 379, doi.org/10.1017/s00208183 00018993.

6 See Robert Howse, 'From Politics to Technocracy ... and Back Again: The Fate of the Multilateral Trading Regime' (2002) 96 Am. Journal of International Law 94; A Lang, World Trade Law After Neoliberalism (Oxford University Press, 2011), doi.org/10.2307/2686127. 
The mid-1990s was also a time of growing challenges to the autonomy and power of the state and, indeed, to the Westphalian international order itself. The sources of these challenges were varied, and they clustered at the infra- and transnational as well as the supranational level. Some disruptions emanated from the proliferation of new international regimes and tribunals, of which the WTO itself was a prime exemplar. The sheer variety and number of normative regimes along with the burgeoning institutions that had emerged to support them on the international plane provoked worries about legal 'fragmentation'. ${ }^{7}$ They ensured, at minimum, that there would be competing perspectives and determinations on central international legal questions; at maximum, there would be unresolved conflict that seemed to threaten the authority of law itself. But challenges to the authority of the state, as well as to the international legal order, also came from new forms - and greater usage - of transnational law and nonstate norms promulgated by private parties. ${ }^{8}$ Indeed, the fragmentation and destabilisation of international law was itself linked to the emergence of 'new governance' - broadly speaking, alternatives to classic, top-down forms of governance and regulation promulgated by the state or through interstate agreement - to manage problems and processes of global and regional economic integration for which traditional state-based approaches were, it was often claimed, ill-suited or simply inadequate. ${ }^{9}$

Yet a third destabilising dimension or development also reared its head: the problem of empire, ensuing from the singular role the US was then in a position to play as the sole hegemonic power remaining after the end of the Cold War. ${ }^{10}$ That position enabled the US both to use international legal institutions as mechanisms to further its interests and projects, but equally to ignore international law when it suited its purposes.

7 For a discussion, see International Law Commission, Fragmentation of International Law: Difficulties Arising from the Diversification and Expansion of International Law, UN Doc A/CN.4/L.682 (13 April 2006) ('the Koskenniemi Report'); Andreas Fischer-Lescano and Gunther Teubner, 'RegimeCollisions: The Vain Search for Legal Unity in the Fragmentation of Global Law' (2004) 25 Michigan Journal of International Law 999.

8 Philip Jessup, Transnational Law (Yale University Press, 1956); Peer Zumbansen, 'Transnational Law', in J Smits (ed), Encyclopaedia of Comparative Law (Edward Elgar Publishing, 2006).

9 Gráinne de Búrca and Joanne Scott (eds), Law and New Governance in the EU and the US (Hart, 2006).

10 Martti Koskenniemi, 'Constitutionalism as Mindset: Reflections on Kantian Themes about International Law and Globalization' (2007) 8 Theoretical Inquiries in Law 9, doi.org/10.2202/15653404.1141. 
If only because its birth was so deeply interconnected with these changes, the WTO seemed to provide a convenient, even inevitable, point of departure for the examination of myriad associated questions of governance. The Uruguay round negotiations out of which the WTO emerged had already pushed established boundaries on the settlement between the national and international, for example in debates about nontariff barriers to trade, intellectual property rights and trade in services. Thus, debates about the uses and efficacy of the WTO were immediately entangled in debates about where and how to conduct political debate over matters of policy as well as justice, transnational as well as domestic, and how to ensure democratic input and control over these matters in a dynamic international order in which many of the ordinary channels for democratic deliberation seemed blocked, destabilised, missing or simply unclear.

If at this point the WTO seemed the centre of global governance debates tout court, viewed in retrospect, the picture looks quite different. At a time when multilateralism is in decline and regionalism on the rise in trade relations, central organs of the WTO like the Appellate Body are in crisis, and trade negotiations are once again sites for the assertion of national interest and competing geopolitical projects, that moment seems less the dawn of a new 'universal' era organised through rules-based global commerce than the beginning of a highly differentiated world, one paradoxically furthered by a commitment to the universalising possibilities of market ordering itself. The sentiment of hopefulness that the WTO represented concerning the political possibilities of law appear now to be not only transitory but even aberrational. ${ }^{11}$ And whatever their putative relationship within liberal theory, the connections between democracy, liberalism and markets are now frayed, evident in the rising number of authoritarian leaders and regimes as well as the many strains on the most famously successful market integration project, the EU, emanating from states as disparate as Greece and Britain.

But as crucial as the broad international context indisputably was to the project, it seems important to flag the highly local one too. At the time CWTO began to take shape, its author was part of a cohort of graduate students at Harvard Law School, one that, at least by previous standards, was both unusually diverse in its composition and distinctly

11 Lang, World Trade Law (n 6); see below n 21 R Wai, 'Normal Trade Law'. 
heterodox and expansive in its approach to legal scholarship. Both in collective discussions and within their individual projects, these scholars were reflecting on the conceptual, legal and political conundrums which these interlinked developments on the international horizon threw up and puzzling through their implications for international law, justice and politics. Questions of development, South-North relations and histories of colonialism were all central to the inquiry, but so was consideration of received disciplinary traditions and institutional forms. Debates invariably engaged innovations in social and political theory that transcended the discipline of law as well. In short, within this community, it was common ground that a vastly expanded lens and a wide array of analytic tools were critical to assessing the trajectory and import of the emerging international legal order as well as to comprehending its past.

As the scholarly writing generated by those scholars' documents, that community proved to be an immensely fertile laboratory for new even revolutionary - forms of critical scholarship in the field. ${ }^{12}$ As her writing from this period attests, Deborah was a central interlocutor in the key intellectual debates, ${ }^{13}$ and their imprint remains visible throughout $C W T O$.

\section{Setting the Stage: The International Context}

What follows is an admittedly motivated reading of $C W T O$, one animated by a desire to surface its engagement and continuing connections with debates about law and development on the one hand and global governance and democracy on the other. There are three reasons that make it seem defensible to read CWTO in this way. The first is that the analysis itself overlaps so much with those scholarly debates that we could now safely place $C W T O$ within these literatures. The second is that questions of development and global governance and their impact on the aspirations of democratic governance are where CWTO itself ends up; by the end of the analysis, we get very clear indications that these concerns

12 Along with The Constitutionalization of the World Trade Organization, among the texts that emerged from that period were Antony Anghie's Imperialism, Sovereignty and the Making of International Law (Cambridge University Press, 2004) and Balakrishnan Rajagopal, International Law from Below (Cambridge University Press, 2003), doi.org/10.1017/CBO9780511494079.

13 Deborah Cass, 'Navigating the Newstream' (1996) 65(3) Nordic Journal of International Law 341. 
are where the author's heart lies, and where if it had been at all possible, her scholarly and analytic attention would next have gone. The third is, of course, that these questions lie at the heart of the political conundrums in which we now find ourselves.

\section{The WTO and Global Economic Transformation}

Like many other writings of its time, CWTO is suffused with the widely shared understanding that something big was afoot with the creation of the WTO. Put simply, everyone perceived that its emergence represented a signal change in the international order, something beyond simply the outcome of the latest round of negotiations that had formed the ordinary business of international trade law since the end of World War II. Rather, the creation of the WTO represented a new settlement in the international economic order, one that went a long distance to displace trade relations based primarily on the political management of interstate conflict with those more closely tethered to the technocratic processes of dispute resolution that gave enhanced role to rules-based adjudication. In the process, the new trade regime opened up new avenues to alter the balance of power between the domestic and the international.

When $C W T O$ was written, the WTO sat at the apex of the international economic order. The WTO had a number of features that made it seem both powerful and effective as an institution and as a regulatory regime, particularly in comparison to those elsewhere in the international order. These features, in turn, caused people to think that the WTO might serve as a prototype for future institutional development in the international arena; for some, the WTO could even be imagined as a vehicle for global governance writ large. ${ }^{14}$ The WTO housed the pre-eminent international dispute resolution tribunal, the new Appellate Body, that was empowered to judicially review the decisions of panels of first instance and thereby authoritatively pronounce on the conformity of policy decisions of national legislatures and executive bodies with global trade rules. At the same time, the institution of the new reverse-consensus rule concerning the adoption of panel decisions moved the management of trade disputes out of the realm of diplomacy and more decisively into the realm of technical, rules-based adjudication. These changes gave the panels and

14 Marco Bronckers, 'More Power to the WTO?' (2001) 4 Journal of International Economic Law 41,44 . 
bodies charged with adjudication enhanced power and importance. These features made the WTO seem not only like an effective institution for rule enforcement and thus a compelling model in other areas of international economic law: as the burgeoning literature on 'trade linkage' during this period of time confirms, they induced scholars and activists working in areas such as labour, the environment and human rights to devise ways to attach their normative and regulatory agendas to the WTO's laws and enforcement mechanisms. ${ }^{15}$

All of these developments generated enthusiasm, but they provoked deep unease in equal measure. The subtitle of CWTO says it all: Legitimacy, Democracy and Community in the International Trading System is a concise encapsulation of the concerns around which debates about trade law and global economic governance were beginning to congeal. As the controversies around the 'mega-regional' trade agreements such as the recently concluded Comprehensive and Progressive Transpacific Partnership (CPTPP) and the proposed Transatlantic Trade and Investment Partnership (TTIP) between the US and the EU confirm, it remains a remarkably well-targeted statement of the preoccupations around which they continue to revolve. ${ }^{16}$

We might style the large question that CWTO is grappling with as follows: how to analyse and assess the organisation of global economic and political order, once the settled understanding about the respective roles and competences of nation-states and international institutions has become disrupted; when the conventional disciplinary narrative within international law about the sovereign equality of states in the Westphalian order no longer persuades at either the descriptive or programmatic levels; and when it has become evident that ever-deeper market integration has become, by design and by default, both the engine reconstituting global political and economic relations and the very problem to be managed. Thus, we can think of $C W T O$ as a point of entry into a broad range of issues - normative, institutional, political - connected to the governance of the international economic order writ large.

15 Robert Howse and Makau Mutua, Protecting Human Rights in a Global Economy: Challenges for the World Trade Organization (International Centre for Human Rights and Democratic Development, 2000), doi.org/10.1163/221160800x00037.

16 See for example, Eyal Benvenisti, 'Democracy Captured: The Mega-Regional Agreements and the Future of Public Law' (Working Paper No 2/2016, Institute for International Law and Justice, New York University School of Law, 2016). 
CWTO is in constant conversation with the developments - legal, social and political - in the international order that were coterminous with the creation of the WTO and which helped cement its status as the pre-eminent international economic institution. One is the mainstream consensus about the benefits of trade liberalisation and extensive market integration; another is the changing normative landscape against which the WTO itself operates, from the move to 'regulation' to the embrace of a constellation of private as well as public mechanisms to address governance and policy concerns. At its heart, however, is a systematic engagement with the principal interlocutors on what are still broadly recognised as the 'big questions' of international economic law. These include: John Jackson, Ernst-Ulrich Petersmann, Robert Howse and Armin von Bogdandy on the perils and possibilities of the emerging regional and multilateral trade and market integration projects; ${ }^{17}$ Joseph Weiler, Neil Walker and Guenter Frankenberg on the conundrums of constructing responsible and responsive political community beyond the nation-state; ${ }^{18}$ Dan Tarullo and Brian Langille on the 'baseline' problem that besets all efforts to establish the legal parameters of a free market; ${ }^{19}$ and Robert Wai on the significance of private law and private ordering to the conduct of international economic transactions, something that trade law, as a branch of public law, leaves out of view. ${ }^{20}$

17 John H Jackson, The World Trade Organization: Constitution and Jurisprudence (Royal Institute of International Affairs, 1998); Ernst-Ulrich Petersmann, Constitutional Functions and Constitutional Problems of International Economic Law (University Press, 1991); Robert Howse (ed), The World Trading System: Critical Perspectives on The World Economy (Routledge, 1998); Armin von Bogdandy, 'Law and Politics in the WTO - Strategies to Cope with a Deficient Relationship' in JA Frowein and R Wolfrum (eds.), Max Planck Yearbook of United Nations Law (Kluwer Law International, 2001) vol 5, 609, doi.org/10.1163/187574101x00169.

18 Joseph HH Weiler, The Constitution of Europe (Cambridge University Press, 1999); Neil Walker, 'The EU and the WTO: Constitutionalism in a New Key' in Gráinne de Búrca and Joanne Scott (eds), The EU and the WTO: Legal and Constitutional Issues (Hart Publishing, 2001) 31, doi.org/10.5040/ 9781472562630.ch-002; Guenter Frankenberg, 'The Return of the Contract: Problems and Pitfalls of European Constitutionalism' (2000) 6 European Law Journal 257, doi.org/10.1111/1468-0386.00107. 19 Dan K Tarullo, 'Beyond Normalcy in the Regulation of International Trade' (1987) 100 Harvard Law Review 546, doi.org/10.2307/1341113; Brian Langille, 'General Reflections on the Relationship of Trade and Labor (Or: Fair Trade is Free Trade's Destiny)' in Jagdish Bhagwati and Robert Hudec (eds), Fair Trade and Harmonization: Prerequisites for Free Trade? Vol 2: Legal Analysis (MIT Press, 1996) 231. 20 Robert Wai, 'Transnational Liftoff and Juridical Touchdown: The Regulatory Function of Private International Law in an Era of Globalization' (2002) 40 Columbia Journal of Transnational Law 209. 
It is clear in retrospect that, as an institution, the WTO has had its own rise and fall narrative. ${ }^{21}$ International economic law no longer pivots exclusively around the WTO; even within trade law, the centre of gravity when it comes to political negotiation and institutional innovation has shifted from multilateral trade to bilateral and regional trade and investment regimes. Yet in all these new arenas, there are the immense unresolved struggles about how to both conceptualise and manage the legal, institutional and normative concerns that have been central to the WTO since its inception. Fortunately for us, it is these very matters that lie at the heart of $C W T O$.

\section{The WTO and Constitutionalism}

It is worth emphasising that $C W T O$ is as much a study of constitutionalism as it is an analysis of trade law or international economic law. There are good reasons to think about the WTO - and other projects of global legal transformation - through the lens of constitutionalism. Even those attempting to come to grips with the governing structures of networks and social systems now employ constitutionalism as a heuristic. ${ }^{22}$ In short, constitutional norms, values and discourse have been embraced to assess the workings of private power and the manner in which non-state entities as well as states effectively 'rule'.

One compelling reason for this expanded use is that constitutionalism is the framework which liberal theory and polities conventionally use to design and evaluate basic matters of the allocation of power and competences. Within the ambit of constitutionalism fall the distribution of powers as between different governing entities, the state and its citizens, as well as the institutions and processes by which disputes about these powers are disposed of. But constitutionalism, of course, serves wider normative and discursive functions concerning matters of political, economic and social organisation and coexistence. Constitutionalism is the language in which legal and political scholars conventionally conduct debates about foundational questions of representation, participation and democracy. Constitutionalism and constitutional rights are, of course, also part of the popular vernacular, a mechanism for voicing concerns about the exercise and legitimacy of power, both private and public.

21 R Wai, 'Normal Trade Law', draft on file with the author; Lang, World Trade Law (n 6).

22 See, eg, Gunther Teubner, Constitutional Fragments: Societal Constitutionalism and Globalization (Oxford University Press, 2012). 
As it turns out, controversies about all of these issues surround the WTO. Constitutional norms and values were widely used in the early years to celebrate the WTO; as Deborah Cass noted, constitutional challenges to the basic structure of the WTO were few, due to what she rightly identifies as 'the pervasive consensus about the benefits of trade liberalization'. ${ }^{23}$ Indeed, many scholars cited the institutional features most familiar from liberal constitutional orders as conclusive evidence of the new trade regime's superiority over the old. Yet over time, constitutionalism's value as a means of challenging, even impugning, these very institutional features has become more evident. Deborah Cass's signal contribution was to recognise early on that the rise of the discourse of constitutionalism in respect of the WTO was related to the challenges that the WTO posed to international law and to the international order, particularly in respect of norms of democratic choice and participation. Thus, she perceived that constitutionalism could be used not merely in its most familiar mode or guise, as a means to defend and advance the WTO, but productively, as a heuristic to reveal much about what might be normatively problematic - even pathological - about its governance structures. Above all, constitutionalism provided a means to critically consider perhaps the most significant aspect of the WTO: the immensely expanded scope it seems to provide both to international technocrats and to private actors to challenge domestic rules and policy decisions, and the troubling constraints on democracy that thereby ensue. ${ }^{24}$

\section{The WTO, Ideas and Knowledge Practices}

CWTO is perhaps most fundamentally a work about the role and power of ideas and ideational frameworks in the governance of international economic relations. It seems important to stress how novel and important a contribution it made for this reason alone. At the time that $C W T O$ was being written, scholars were producing myriad doctrinal and institutional analyses of the new WTO; for international economic lawyers during the 1990s, engaging in that enterprise was arguably the only game in town. Any review of the relevant journals during that time will disclose article after article parsing the new rules of the regime, examining the scope of the powers of the new Appellate Body, and/or taking sides in the decisions it was beginning to render.

23 Cass, The Constitutionalization of the World Trade Organization (n 1) 79.

24 For a sophisticated analysis of the multiple factors and forces that lie behind the widened scope of the trade regime, see Lang, World Trade Law (n 6). 
Deborah Cass, however, was one of the first people to seriously consider that the idea of the WTO - how it was conceived as an institution, how it imagined the community of states and other actors engaged in trade relations, and the ethos and values that organised these relations and informed the operation of the regime as a whole - was an independently significant field of inquiry. It is the deep and systematic inquiry of CWTO into the structures of thought organising the new trade regime, as well as the beliefs and claims about constitutionalism, liberal values and human rights to which the institution quickly became attached, that ultimately make it of such enduring value. For in the intervening period, it has become abundantly clear that when it comes to international economic law, institutions rule the world. It is in the realm of ideas, and the knowledge practices through which people and institutions give life and substance to those ideas, that the big battles are fought, large transformations are affected, and significant stakes, political as well as economic, for particular parties disposed. ${ }^{25}$

Deborah Cass was unusually alert to the fact that the emergence of the discourse of constitutionalism in and around the WTO was bound up in a host of aspirations intimately connected to a broader project of global economic and political transformation. As she noted, constitutionalism served as a form of wish fulfilment, a means of marking fundamental change in the global order, of separating the past from the present, and creating new legal obligations even - perhaps especially - where it was far from clear what intentions and circumstances warranted. ${ }^{26}$ In short, the discourse of constitutionalism was itself doing a huge amount of transformative work, work that promised - or threatened - to take international trade law well beyond where trade negotiations had themselves taken it, even given the momentous results of the Uruguay round.

\section{The Strategy}

How to tackle such a mammoth task? Here is how the author takes up the challenge.

After a brief outline of the origins of the constitutionalisation debate surrounding the WTO, CWTO proceeds directly to a 'received account' of constitutionalism itself. This account first distils and then arrays the

25 Lang, World Trade Law (n 6); David Kennedy, A World of Struggle: How Power, Law, and Expertise Shape Global Political Economy (Princeton University Press, 2016).

26 Cass, The Constitutionalization of the World Trade Organization (n 1) 69. 
essential elements of constitutionalism as a mode of conceptualising legal, political and institutional relations, with the aim of providing a means to assess the status and transformation of the fundamental relations of the trade regime. The function of this account, the author emphasises, is less to crystallise a conception of constitutionalism in any essential or absolute sense, than to provide a set of yardsticks with which to measure various claims and accounts of constitutionalism as they are applied to the WTO.

To this end, Deborah Cass identifies six elements or features of constitutionalism, unfolding an idea about to how think about each of them. She then moves on to link debates about the constitutionalisation of the WTO to developments within international economic law scholarship.

The six identified elements of constitutionalism are constraints on social, political and economic behaviour; Grundnorm change; community; deliberation; realignment of relationships; and legitimacy. I will only note in passing the immense command of constitutional theory and scholarship that the construction of this compelling 'received account' required, as well as the significance of that mastery to the project at hand. Only someone with deep knowledge of public law norms, institutions and doctrines at the domestic level could have detected so many gaps and slippages in the efforts to transpose constitutional norms and heuristics onto the international plane in the first place. And only a person so situated could have fully explored and displayed the manner in which that transposition then enabled an immense and divergent range of claims and aspirations to be projected onto the WTO.

Deborah Cass has a specific argument about how that scholarship, in her words, 'fueled the promotion of the constitutionalization of the WTO'. ${ }^{27}$ The first step is the discipline's preoccupation with and characterisation of the WTO as an institution as such, as opposed to a mere treaty or set of rules. The second, highly consequential step, is the elision between institution and constitution. As against this characterisation, Deborah Cass insists on a distinction. Even if we are prepared to characterise the WTO as an institution, in the absence of the attributes of constitutionalism already outlined, an institution, she points out, cannot 'simply metamorphose' into a higher order institution or constitution. ${ }^{28}$ For the apparent success of this conflation or metamorphosis, the belief and acceptance within the

27 Cass, The Constitutionalization of the World Trade Organization (n 1) 62.

28 Ibid 60. 
discipline in 'the WTO as a thing in itself, a regime, a concept which is more than the sum of its parts', ${ }^{29}$ has everything to do with the conferral of enhanced legitimacy and authority on the WTO. As she notes, this is a highly problematic move: it immediately imports a set of powerful ideas into the trade regime, some of which are fundamentally alien to it. One is the belief that non-discrimination rights concerning market access, long a part of multilateral trade law, are human rights, rights moreover that domestic courts can apply and that 'citizens can rely on ... to challenge state action'. ${ }^{30}$ Constitutionalism can also serve what she describes as a 'door-closing' function, insulating the WTO from critique to which it would otherwise be subject and thereby reifying its particular institutional features. ${ }^{31}$ International economic law scholarship operating in the mode of constitutionalism also fosters an easy linkage between the WTO and developments that might otherwise only be contingently associated with neoliberal globalisation. That risk or possibility is, in her assessment, especially live, given the detachment of disciplinary debates within international economic law from earlier calls for a New International Economic Order. Although there are still dissident voices, the critical tradition within international economic law is, in her estimation, 'small in number and low in profile'. ${ }^{32}$ The community of international legal scholars, then, has a lot to answer for.

$C W T O$ then proceeds to examine three basic variants of constitutionalism associated with the WTO, analysing them through the claims of the scholars and personages with whom they are most prominently identified. It is worth noting that all of these variants circulate as central pillars of the mainstream support and defence of the WTO, and all are in some sense interrelated. The three variants are institutional managerialism; rightsbased approaches; and judicial norm determination.

This constitutional typology proves to be immensely successful, and the analysis of these variants is really the heart of the book. As a heuristic, it not only allows us to examine in a systematic way what otherwise might appear to be a quite chaotic set of issues, themes, trends and arguments: it also permits us to grasp the distinct social and political visions that

29 Ibid 101.

30 Ibid 69.

31 Ibid.

32 Ibid 81. 
animate different claims, and to do so, moreover, in a way that helps reveal precisely how and why those visions might also be such a cause of worry for the WTO's critics.

\section{Institutional Managerialism}

Institutional managerialism, identified foremost with the work of John Jackson, involves not just the juridification of trade disputes and the move to the management of trade by rules as opposed to diplomacy: it also enabled the WTO to manifest as an institution, 'a thing in itself', something more than the sum of its parts. This, in turn, made the project of trade law seem vested with unity and coherence; it also provoked an association between the WTO and democracy. After the appearance of Jackson's The World Trade Organization: Constitution and Jurisprudence, 'the symbiotic relationship between institutionalism and constitutionalism was cemented once and for all', ${ }^{33}$ despite the fact that it had never been 'through the process of democratic authorization by a defined constitutional community'. ${ }^{34}$

How did this chain of associations unfold or 'work', and with what consequences? The superiority of rules-based trade relations over trade diplomacy was a bedrock assumption at the creation of the WTO. ${ }^{35}$ But as the term 'managerialism' is intended to suggest, the adoption of a more stringently rules-based regime brought with it governance by technocratic expertise, a process that empowered trade bureaucrats at the expense of other regime actors in a variety of ways. What was less obvious, at least until the new regime really got going, was how much rule application informed principally by the value of progressive liberalisation of trade might become a way to tilt other values, those associated with democracy and the rule of law in particular, off their axis at the same time.

As many trade scholars have noted, trade law has always operated through and against a background consensus on the proper domain and reach of the regime itself. ${ }^{36}$ The optimism, expressed by Jackson and others, that a practical, pragmatic spirit, along with a few small tweaks to the system, could satisfactorily address any new challenges and conflicts

33 Ibid 101.

34 Cass, The Constitutionalization of the World Trade Organization (n 1) 106.

35 Ibid 115; Lang, World Trade Law (n 6).

36 Lang, World Trade Law (n 6). 
about this fundamental issue generated by the new regime, soon proved unwarranted. For it turns out that there was no logical end point to the claims touching on domestic law and policy that might be advanced in the name of liberalised trade; absent explicit mechanisms of politics and diplomacy, there was also no easy way to limit to the regime's capacity to penetrate domestic legal systems in novel and capacious ways. This tendency was to be powerfully - indeed deliberately - reinforced by the next pillar of trade constitutionalism.

\section{Rights-Based Approaches}

Rights-based approaches are prescriptive calls for a radical transformation of the trade regime. Based on a combination of strategic and normative rationales ${ }^{37}$ and more openly values-based than institutional managerialism, the constitutional innovation of rights-based approaches is to represent the WTO as 'a system of protection for individual economic rights beyond national borders' ${ }^{38}$ Beginning life as a means 'to facilitate the direct effect of WTO law into national legal systems' and going further through the door that had already been opened under the North America Free Trade Agreement's Chapter 11 provisions, rights-based approaches rest the legitimacy of the WTO on the extent to which it allows the voice and interests of private actors a direct role in the instigation and management of trade disputes.

Rights-based approaches are what Deborah Cass calls frankly ideological, even 'messianic' approaches to the world economic order. Here, we encounter not (just) a world of order and agreement among states, but a vision of a transnational community of rights-bearing citizen-consumers marching into a future of trans-border economic deals, all under the banner of private rights. Like institutional managerialism, the recognition of private rights, too, facilitates the use of WTO as a constraint on the reach and interpretation of domestic law by, for example, providing a basis on which to subject national legislation to judicial review based on WTO agreements. ${ }^{39}$

37 Cass, The Constitutionalization of the World Trade Organization (n 1) 162.

38 Ibid 146.

39 Ibid 148. 
The resuscitation and advancement of a private right to trade,${ }^{40}$ cast not just in the language of rights but in the language of human rights is, in the author's assessment, a powerful legitimating move. This is surely correct: once transmuted into the language of human rights, rightsbased approaches become an effective mode of self-legitimation as well as a source of enhanced authority for the WTO. ${ }^{41}$ Replacing open political contestation over competing aims and values with claims rooted in fundamental moral and ethical precepts, rights-based approaches enable their proponents to bootstrap the status of a radical reconceptualisation of trade law, one that would fundamentally alter its reception into national legal systems and give private actors privileged status in international law to boot, ${ }^{42}$ by linking it - normatively and semantically - with Kantian liberal political theory and highly individualist ideas about human freedom and human dignity.

Setting aside entirely the fact that the claimed 'right to trade' can charitably be described as obscure (no reference to any such right can be located in any human rights treaty, for example), it turns out that moralising about free trade is a bad idea for other reasons. For one, hanging the case for free trade on individual moral rights has proved to be an effective way to delink free trade from the broader welfare goals on which the postwar multilateral trade regime found much of its original justification. For another, it provides a means to insulate trade rules from any accounting of consequences or trade-offs with other rights. It forms no part of the rights-based approach, for example, that losses to some are not just an unintended side effect of liberalised trade; they are how the gains of trade are realised. ${ }^{43}$ For both reasons, absolutist approaches to private rights undercut the normative and analytic basis on which states might try to temper the destabilising effects of liberalised trade on their populations.

It was surely correct on Deborah Cass's part to mark the significance of rights-based approaches to trade; indeed, it now looks prescient. Although inchoate and still aspirational when she wrote, efforts to give enhanced status to private rights at the level of process and substance have become only more muscular and well-developed in the international

40 The right to trade had long been invoked in international law; see, eg, Hugo Grotius, The Rights of War and Peace, tr AC Campbell (M Walter Dunne, 1901) <http://oll.libertyfund.org/titles/grotiusthe-rights-of-war-and-peace-1901-ed>.

41 Cass, The Constitutionalization of the World Trade Organization (n 1) 151.

42 Cass, The Constitutionalization of the World Trade Organization (n 1) 153.

43 Howse, 'From Politics to Technocracy' (n 6). 
economic order in the intervening time. For example, private investorstate dispute resolution provisions have been a key feature - and major source of contention - of many of the trade and investment regimes now under negotiation, in particular the 'mega-regional' trade and investment treaties like the TTIP and the CPTPP that have taken centre stage as multilateral negotiations have stalled or been abandoned.

The standardisation of private rights to trade and transact is arguably even more central to other initiatives in the international economic order, especially those designed to set normative benchmarks for economic rules and institutions. For example, the extent to which states grant adequate, or enhanced, protection for private rights serves as a key metric of many of the regulatory reform programs that the World Bank, including its flagship Doing Business, project. ${ }^{44}$ The same objective arguably animates the OECD's projects on regulatory quality and regulatory coherence, evident in the extent to which it, on the one hand, privileges the goals of efficiency and on the other, avoids discussion of welfare objectives. ${ }^{45}$ Indeed, the chapter on regulatory coherence within the CPTPP is designed to further such goals, at the same time as it normalises the objective of reducing regulatory differences. ${ }^{46}$ In short, the broader world of international economic law is now suffused with the same constitutionlike vision of transnational private rights.

\section{Judicial Norm Development}

The third approach, judicial norm development, locates the engine of the regime's constitutionalisation in the new institutional innovation, the WTO Appellate Body. Like reviewing courts in common law jurisdictions, the Appellate Body operates in constitutional mode by reflecting the governing norms of the institution, and through the accumulation of case law, by building those norms at the same time. ${ }^{47}$

In a layered, nuanced account, Deborah Cass takes the opportunity to point out the deficiencies of judicial norm generation within the WTO as measured by constitutional yardsticks, the obvious model and predecessor

44 World Bank, 'Doing Business 2020', Doing Business (Web Page, 2020) <https://www.doing business.org/>.

45 See for example, OECD, Regulatory Policy and the Road to Sustainable Growth (OECD, 2010).

46 See Government of Canada, Global Affairs Canada (Web Page, 9 November 2019) <https://www. international.gc.ca/gac-amc/index.aspx?lang=eng>.

47 Cass, The Constitutionalization of the World Trade Organization (n 1) 178. 
being Joseph Weiler on the role of the European Court of Justice on the transformation of the European Community. ${ }^{48}$ Following von Bogdandy, her emphasis is on the constitutional inadequacies that follow from the introduction of a system of judicial review that operates on its own, not counterbalanced by anything like an adequate political branch or legislature. As she describes, democratic values are compromised by the absence of a deliberative body, while the outsourcing of rule-making to standard-setting bodies risks subjecting those rules to capture by private actors. Moreover, the introduction of judicial review turns out to alter the relationships between the central actors in the trade regime in fundamental ways. Among the consequences is the erosion of the longstanding international law rule that the state is the ultimate arbiter of how international obligations are implemented. Appellate review, too, boosts the role of technocratic trade-biased decision-makers over political decision-makers, for example, by compelling states to advance a scientific rationale when assessing questions of risk and defending their legislative choices, even though such rationales are, on their own, an inadequate means of resolving the political and economic controversies that invariably underpin policy and regulatory decisions.

\section{On Constitutionalism and the Trade Regime: Costs and Benefits}

The cumulative effect of these different constitutional lenses is both impressive and so revealing as to be transformative. By the time the analysis is finished, we have in full view a deep conundrum: although the language of constitutionalism is everywhere to be found in respect of the WTO, on almost any angle the regime seems constitutionally deficient. All three approaches to the defence and explication of the WTO, it turns out, come up short when measured against normal expectations about constitutional orders, whether it concerns matters of form, content or process.

Above all, through the discourse of constitutionalism, CWTO suggests the immense stakes of trade regimes that threaten to slip the expectations, and even the grasp, of their creators.

48 See, eg, Weiler, The Constitution of Europe (n 18). 
To recapitulate, $C W T O$ makes clear the risky, unstable settlement between the domestic and the international when it comes to foundational decisions about social and economic priorities that the new regime has imported and inaugurated. Here, the crucial issue is the constraints on policy space faced by states when it comes to implementing any rule or decision that might have an effect on the allocation of risk or the costs and benefits of trade. This is now arguably the central theoretical and political question for trade negotiations as a whole. In so doing, CWTO also foregrounds the shifting balance of power between the domains of politics and technocracy, and the declining role of diplomacy in favour of expertise in the trade regime. CWTO marks the rising status of the individual or corporate actor vis-a-vis nation-states within the trade regime enabled by the mechanism of private rights, now transposed into 'human rights', and the deep challenge to democratic values posed by that ascendancy. As a consequence of the previous three moves, CWTO also highlights the uncertain and imperilled status of non-economic or social concerns here, read distributive equity and social justice - in the current trade law calculus. Finally, CWTO focuses our attention on the vexed problems of constructing institutions and rules for representation and deliberation in a post-Westphalian world, where whether at the descriptive or normative level, states are manifestly no longer the only actors in town. ${ }^{49}$

CWTO makes equally clear the mechanisms and vectors of this transformational change. Here, we need to return to the role of ideas and recall the leitmotif running throughout $C W T O$, the independent significance of using constitutionalism as the frame in which to reflect on and measure such concerns. Throughout, the author draws our attention to the discursive function of constitutionalism, the fact that in applying the language of constitutionalism to the WTO, we have already made a significant move to import a host of legitimating assumptions and operations into the regime. Here she notes the 'door-closing' function of constitutionalism: its capacity to reify features that we might well have reason to question, but also its opposite - the possibility that constitutional discourse will facilitate the extension of the WTO into so many areas in which its authority is both uncertain and contentious. In describing the easy slippage from the apparent 'fact' of a new trade institution to the claim that that institution has, or should be endowed with, enhanced

49 Nancy Fraser, Scales of Justice: Reimagining Political Space in a Globalizing World (Columbia University Press, 2009). 
status, Deborah Cass displays a remarkably good ear for the false note: for example, the way that constitutionalism both constructs and fuels a false antinomy between the individual and an all-powerful state, paradoxically in an era when private actors and entities have unprecedented reach and power.

\section{The Constitutionalisation of the WTO: Signposting the future}

CWTO is relentlessly analytic and taxonomic; it is also exhaustively and at moments exhaustingly - even-handed in its treatment of the merits of different constitutional arguments. Yet an undercurrent of normative energy and disquiet threads its way throughout the analysis nonetheless; by the last chapter, that undercurrent finally bubbles up in full view. If Deborah Cass has not changed her mind about the value of the constitutional inquiry tout court, then by the end she is very clear about two interconnected problems.

The first problem concerns the limits of transposing the discourse of constitutionalism from the nation-state to the international sphere. Deborah Cass's systematic inquiry into the WTO throws into sharp relief the inadequacies that attend the projection of norms, assumptions and practices of domestic constitutionalism onto the international level. Here, we might read her as a critic, engaging in the exercise of foregrounding the background. As the exercise in reversal reveals, a host of institutions and practices associated with the nation-state operating in normal, liberal mode turn out to be crucial to the defence - and even the intelligibility of constitutional norms, although many form no part of the conversation about constitutionalism and the WTO. If some or many of those practices and institutions are absent, weak or distorted, then constitutionalism will both mean and do very different things than we ordinarily understand it to mean and do. This is, of course, precisely what she has demonstrated with respect to the various models of constitutional engagement with the WTO.

The second problem concerns not just the limits but the pathologies of such exercises in projection, as it becomes clear that dominant ideas of constitutionalism so often work to further those aspects of the WTO that are most problematic. Here, Deborah Cass identifies problems with 
constitutionalism at both the descriptive and the normative levels. Not only are existing models for analysing the WTO 'deeply unsatisfying', but in her view, 'the ascendancy of these particular models of constitutionalism is related to (these) perceived deformities of democracy, sovereignty and economic and political organization in the international order'. ${ }^{50}$ These are tough words. If modes of political and institutional analysis developed within and premised upon the nation-state are not easily transposed into the supranational register, if the use of constitutionalism in the international sphere can even perform a sort of reverse alchemy, turning the gold of cherished political values into leaden constraints against democratically responsive modes of governance, then what comes next?

The final, quite short but powerful, indicative chapter gives us a pretty good idea of where she, and we, might go. For CWTO ends with a normative/ reconstructive project; Deborah being always unhappy with intellectual ventures that stopped short of reform, 'what is to be done' being very much part of her orientation both as a scholar and as a human being.

In an earlier venture, 'Navigating the Newstream: Recent Critical Scholarship in International Law', Deborah Cass took stock of a loosely consolidating, though still nascent, critical engagement with 'mainstream' international law. While crediting critical scholars with crucially important insights into the discipline, she also took them to task for failing to adequately take those insights forward. Here's how she saw the promise, and limits, of critical scholarship:

as pedagogical tools, the Newstream writings are invaluable because they offer plausible explanations of international lawmaking, interpretation and application, at a point in time in which traditional understandings about law have been questioned by (post)modern insights into cultural fragmentation, the making of history and the role of language in law. ${ }^{51}$

Yet 'while these Newstream challenges could be transformative tools of changing law their potential is largely unrealized'; '52 '[n] ewstream critiques frequently seem to pull back from the brink of affecting real change in international dialogue. ${ }^{53}$ For example, while analyses of the culture of international law are

50 Cass, The Constitutionalization of the World Trade Organization (n 1) 245.

51 Cass, 'Navigating the Newstream' (n 13) 343.

52 Ibid 345.

53 Ibid 378. 
partially persuasive, they ... leave unanswered the question of how international law can be loosened from the particular cultural moorings it has acquired over time and which are now represented in Mainstream literature. ${ }^{54}$

It was already clear long before $C W T O$, then, that deeply probing and sceptical inquiry into the conceptual scaffolding of mainstream legal scholarship, however necessary, could only ever, in Deborah's view, be part of the enterprise; no adequate account of the trade regime would stop there. To avoid these deficiencies, Deborah Cass has a quite specific suggestion: that constitutionalism debates in the WTO should be refocused on the ends of democracy and development. This should be done by effecting a merger of a transformationalist mindset with respect to constitutionalism with many of the anti-constitutional critiques already in circulation. We have a very good foretaste of the character of this imagined merger, moreover, having encountered many of these critiques in the course of her analysis of the mainstream constitutional models.

Such a merger would require going well beyond the received accounts of constitutionalism that have been in play so far. For their effect, as the reader can now fully appreciate, has been to inhibit rather than advance the very thinking about the WTO and its place within international economic law that, now as then, is so evidently necessary. ${ }^{55}$ Surfacing not only the question of constitutional forms but also the substantive aims or goals of constitutionalism, this merger would compel us to revisit foundational questions about the distribution of powers among public and private actors and the hierarchy of goals and values in the international order, questions that the debate over constitutionalism has paradoxically foreclosed.

Having performed what is in effect a monumental constitutional ground-clearing exercise, Deborah Cass was poised to delve deeply and directly into these foundational normative and political controversies. The contemporary reader of $C W T O$ might well want to hear much more on precisely these points, if only because they have become the central questions about the international economic law in the intervening time. Yet even as it stops at precisely this point, CWTO remains a brilliant and far-sighted analysis, one infused with highly attuned political intuition that shines continued light on the path on which we now find ourselves.

54 Ibid 350.

55 Cass, The Constitutionalization of the World Trade Organization (n 1) 245. 
This text is taken from Traversing the Divide: Honouring Deborah Cass's Contributions to Public and International Law, edited by Kim Rubenstein, published 2021 by ANU Press, The Australian National University,

Canberra, Australia.

doi.org/10.22459/TD.2021.07 